Review

\title{
Climatic effects on sugarcane ripening under the influence of cultivars and crop age
}

\author{
Nilceu Piffer Cardozo*, Paulo Cesar Sentelhas
}

USP/ESALQ - Depto. de Engenharia de Biossistemas, Av. Pádua Dias, 11 - C.P. 9 - 13418-900 - Piracicaba, SP Brasil.

${ }^{*}$ Corresponding author <nilceu.cardozo@terra.com.br>

Edited by: Daniel Scherer de Moura

Received January 10, 2013

Accepted June 28, 2013
ABSTRACT: The lack of information about the effects of cultivars, crop age and climate on the sugarcane (Saccharum ssp.) crop yield and quality has been the primary factor impacting the sugar-ethanol sector in Brazil. One of the processes about which we do not have a satisfactory understanding is sugarcane ripening and the effects of cultivars, crop age and climate on that. Sugarcane ripening is the process of sucrose accumulation in stalks, which is heavily influenced by several factors, mainly by climatic conditions such as air temperature and water deficits. Because it is a complex process, studies of the variables involved in sugarcane ripening can provide important information, resulting in a better use of commercial cultivars, bringing advantages to growers, processing units, breeding programs and scientific community. In this review, we discuss the available knowledge of the interaction between climate conditions and sugarcane ripening, under the influence of genotypic characteristics and crop age. In several studies, the main conclusion is that sugarcane ripening depends on a complex combination of climate variables, the genetic potential of cultivars and crop management. Soil moisture and air temperature are the primary variables involved in sugarcane ripening, and their combination stimulates the intensity of the process. In addition, the need for studies integrating the effects of climate on plant physiological processes and on the use of chemical agents to stimulate sugarcane ripening is highlighted.

Keywords: Saccharum spp., air temperature, precipitation, water deficit, sucrose

\section{Introduction}

Climate has been the major factor affecting sugarcane (Saccharum ssp.) production in recent seasons in Brazil. The 2009/10 season was marked by several periods with large water surplus associated with an El Niño event, while 2010/11 presented an intense and prolonged drought, associated with a La Niña event. The 2011/12 season experienced a combination of large water surplus at the beginning of the year, two frosts in late fall and early winter and an intense water deficit from the middle to the end of the season. Each of these scenarios brought unique consequences to sugarcane yield and quality and constitutes a clear example of how climate conditions can impact the Brazilian sugar-ethanol sector.

Clements (1962), Lingle and Irvine (1994) and Robertson and Donaldson (1998) have studied sugarcane ripening around the world. In most of the recent studies Lingle (2004), Inman-Bamber et al. (2009), Leite et al. (2011) and Silva and Caputo (2012) have discussed the effects of chemical agents (ripeners) or the biochemistry of the process rather than the natural variables that influence ripening. The main studies on the effects of climate on sugarcane ripening were produced between the 1950s and 1970s (Clements, 1962; Glasziou et al., 1964; Waldron et al., 1967; Alexander and Samuels, 1968; Legendre, 1975). Much of the information produced at that time has not been consolidated and organized in such a way that allows these studies to be used in crop planning and decision-making based on the current conditions of the sugar-ethanol sector in Brazil.
Studies that organize the knowledge available for over 50 years, updated with new studies developed in recent years, are extremely important for the development of the sugar-ethanol sector and for the determination of what new studies should be performed. This review aims to discuss the effects of climate variables on sugarcane ripening, in addition to the effects of genotypes and crop age. Moreover, we highlight the results obtained in recent years, which question common knowledge and indicate the need for further research to increase the comprehension of the sugarcane ripening process.

\section{Sugarcane ripening}

Clements (1962) described sugarcane ripening as a physiological senescence that occurs between the phases of growth and plant death. Generally, ripening is the process of sucrose accumulation in sugarcane stalks (Legendre, 1975), which occurs from the basal internodes to the apex, until they reach a common value (Alexander, 1973). In this way, sugarcane stalks are the reservoir where, under favorable conditions, large amounts of sucrose are accumulated. Sugarcane stalks are composed of successions of internodes in different physiological stages, issued at intervals of approximately ten days. During growth, sucrose content is always greater in basal internodes (older) and lower in younger ones in the top of the stalks. These immature internodes have green leaves, are fibrous and have high hexose concentrations and low sucrose levels. As immature internodes develop, their growth rates decrease until growth is almost completely stopped when the internodes are ripened (Glasziou et al., 1964). 
The ripening point is determined primarily by the levels of sucrose, reducing sugars and stalk humidity during the crop season. According to the Brazilian Sugarcane, Sugar and Ethanol Producers Council (CONSECANA) standards, millable cane, i.e., stalks that have the technological and economic conditions for industrial processing, need sucrose (Pol) levels of at least 12.257 \% (Lavanholi, 2008). Early cultivars are those with Pol levels greater than $12.257 \%$ at the beginning of the harvesting season, while middle and late cultivars possess Pol concentrations above this threshold from the middle to the end of the season (Lavanholi, 2008).

The sucrose levels vary during the harvesting season, with higher accumulation rates observed during the last phase of the sugarcane cycle, when the plant has a low growth rate, which is conditioned by adverse weather conditions (Alexander, 1973). In Southeastern Brazil, the lower air temperature in the fall-winter months combined with the occurrence of a moderate water deficit are the major ripening factors, which result in a very rapid increase in sucrose content. Cardozo (2012) indicated that the sucrose stalk content in the four months before harvesting increased from $7.32 \%$ to $15.29 \%(\approx 110 \%)$, while the total biomass only increased from 122 to $132 \mathrm{t} \mathrm{ha}^{-1}$ $(\approx 8 \%)$. Therefore, despite the intense work of breeding programs to produce earlier-ripening cultivars, sugarcane rarely achieves its full ripening potential, as it is harvested while still actively accumulating sucrose (Legendre, 1975), especially in the first months of harvesting season, when the air temperature and soil moisture are usually high.

\section{Ripening and cultivar characteristics}

The genotype can affect the response of sugarcane to meteorological variables, such as air temperature, precipitation, soil moisture and solar radiation (Brodie et al., 1969). Sugarcane cultivars differ in how long they take to ripen, with early cultivars tending to be more sensitive to weather conditions and therefore ripening sooner. Meanwhile, the late cultivars are less sensitive to weather conditions for ripening, reaching the highest sucrose levels in the end of the harvesting season, which is between the second half of Aug and the first half of Oct in Southern Brazil (Scarpari and Beauclair, 2004).

The ripening of sugarcane cultivars is significantly variable in the early season, when the precocity of cultivars really leads to differences in sugar yield (Cardozo, 2012). However, as the harvesting season progresses, the variation among cultivars in terms of sugar content decreases, and the classification of the cultivars as early-, middle- or late-ripening is no longer evident (Table 1). Cardozo (2012) emphasizes that although the differences in Pol values among cultivars have been reduced during the harvesting season, early cultivars usually tend to keep the highest Pol levels, even though this difference was not as expressive as in the early season. This fact was also reported by Stuppiello (1987), who observed that the mid-season sugarcane cultivars rarely reach the maximum sucrose levels obtained by the early cultivars, and similarly, the late cultivars rarely reach the sucrose levels of the mid-season cultivars.

The response of sugarcane cultivars to environmental conditions is commonly attributed to the differences in their physiology. Singh and Venkatarama (1983) and Lingle and Irvine (1994) observed the highest relative growth rates and net sucrose accumulations during stalk elongation and ripening of early cultivars when compared to late ones. Early cultivars tend to have more synchronized tillering phases and develop complete internodes earlier. The early-ripening cultivars are more physiologically efficient because they use the photosynthates in a more effective way and complete their vegetative growth faster than late-ripening cultivars (Mamet and Galwey, 1999). Thus, they would be physiologically able to change from a vegetative development phase to ripening earlier than the late cultivars. Singh and Venkatarama (1983) suggested that early-ripening cultivars had a lower ratio of acid and neutral invertases, favoring the ripening process. Sugarcane cultivars have distinct reactions in relation to invertase activity and sugar levels. Early cultivars tend to have higher levels of neutral invertase activity earlier than late cultivars, resulting in higher sucrose accumulation and low levels of reducing sugars.

Table 1 - Pol levels of eight sugarcane cultivars over the months of the 2003 season in Piracicaba, State of São Paulo, Brazil.

\begin{tabular}{|c|c|c|c|c|c|c|c|c|}
\hline Cultivars & Mar & Apr & May & June & July & Aug & Sept & Oct \\
\hline SP91-1049 & 9.82 & 11.34 & 13.23 & 14.81 & 15.35 & 16.22 & 16.75 & 17.09 \\
\hline SP90-3414 & 7.25 & 9.15 & 11.27 & 13.14 & 14.40 & 15.67 & 16.59 & 17.12 \\
\hline SP87-365 & 6.65 & 9.21 & 10.87 & 12.57 & 13.34 & 15.16 & 16.13 & 16.61 \\
\hline SP86-42 & 6.02 & 8.54 & 10.30 & 12.27 & 13.18 & 14.72 & 15.78 & 16.54 \\
\hline SP86-155 & 8.61 & 10.18 & 12.54 & 13.87 & 15.12 & 15.74 & 16.17 & 16.79 \\
\hline SP83-2847 & 5.97 & 8.24 & 10.37 & 11.67 & 12.69 & 14.33 & 15.79 & 16.20 \\
\hline RB928064 & 7.12 & 9.52 & 11.83 & 12.44 & 13.44 & 15.20 & 15.75 & 16.69 \\
\hline RB867515 & 7.12 & 8.56 & 11.59 & 12.60 & 13.69 & 15.30 & 15.48 & 16.89 \\
\hline Mean & 7.32 & 9.34 & 11.50 & 12.92 & 13.90 & 15.29 & 16.06 & 16.74 \\
\hline SD & 1.31 & 1.02 & 1.03 & 1.00 & 0.96 & 0.60 & 0.44 & 0.30 \\
\hline CV (\%) & 18 & 11 & 9 & 8 & 7 & 4 & 3 & 2 \\
\hline
\end{tabular}

Source: Cardozo (2012). 


\section{Ripening and crop age}

From a physiological point of view, the processes of ageing, maturity and ripening are not synonymous, although they are usually considered to be so (Alexander, 1973). Maturity has different meanings for different professionals involved with sugarcane production, the most correct being the botanical completion of a stalk, suitable for producing new plantlets from each node. In this case, the stalks will contain stored sugars to support reproduction, but the storage potential of the stalks has not necessarily been achieved. Therefore, maturity is not synonymous with age because if water and nitrogen supplies are continuously available to the plants, they may never reach maturity regardless their age. Moreover, maturity is not synonymous with ripening because sugarcane can be easily ripened within a few months after germination if subjected to water, thermal or nutrient stress. These plants, however, are not mature in any way. From the grower's point of view, maturity, age and ripening have become closely linked in such a way that the ripening process has been conveniently descripted as the culmination of sugarcane maturity.

The effect of the planting date has a much greater effect on crop yield than on ripening (sucrose content) (Cardozo, 2012), which agrees with the findings of Alexander (1973). Over seven different planting dates, the author observed that the variability among Pol levels for each sampling date was negligible throughout the season and was independent of the crop age (Figure 1). However, the stalk yield (Figure 2) varied substantially according to planting time and crop age, with high values of variation coefficient (ranging from 16 to $24 \%$ ). Furthermore, no clear trend of increases or decreases in stalk yield as a function of the time of year was observed, which suggests that biomass production is not only influenced by weather conditions and cultivar characteristics but also by the crop management and sampling. The major

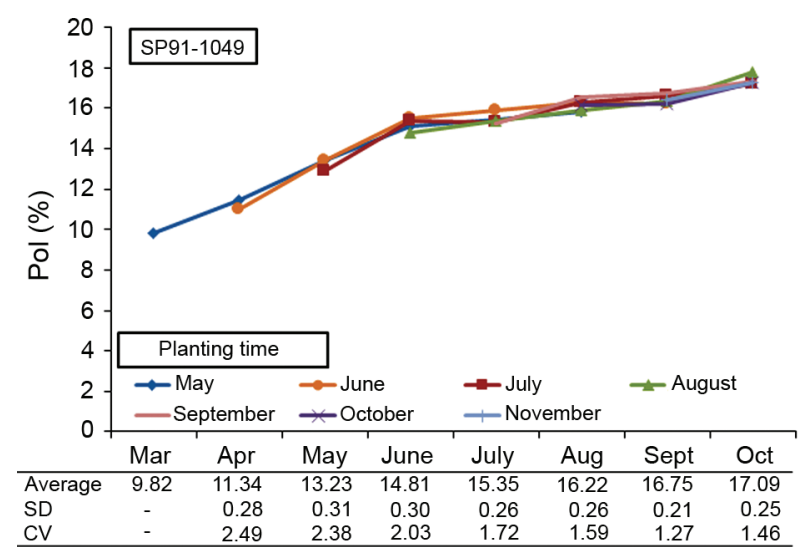

Figure 1 - Pol levels of sugarcane cultivar SP91-1049 during the months of the 2003 season as function of planting time in Piracicaba, State of São Paulo, Brazil. Source: Cardozo (2012). problem with sugarcane biomass sampling is that it is rarely performed in terms of the dry matter of all its components, including pointers, stalks, straw, leaves and roots; which makes the inter-comparisons of results very difficult (Evensen et al., 1997).

\section{Ripening and flowering}

Another factor that affects sugarcane ripening is the flowering process (Silva and Caputo, 2012). Sugarcane flowering is influenced by photoperiod, temperature, rainfall, nutritional status, soil moisture, cultivar and crop management, and is highly undesirable from the sugar production point of view (Alexander, 1973; Pereira et al., 1983). Flowering intensity and the consequences on the juice quality vary according to the interaction between the cultivar and the climate. Reduction of the sucrose and the increase of fiber are the main consequences of the flowering process.

For the majority of sugarcane cultivars used commercially, the required photoperiod in order to induce flowering is between 12 and $12.5 \mathrm{~h}$ (Pereira et al., 1983). Based on that, flowering can be induced all year long in the producing areas close to equator while at middle latitudes $\left(\approx 20^{\circ}\right)$ flowering induction becomes seasonal, occurring in the end of the summer when the days are shortening from 12.5 to $12 \mathrm{~h}$ (Clements, 1968). In addition to the specific photoperiod condition, flowering induction in sugarcane will depend also of temperature, which need to remain between the minimum of $18{ }^{\circ} \mathrm{C}$ and the maximum of $31{ }^{\circ} \mathrm{C}$ (Pereira et al., 1983). Despite the influence of climate conditions on flowering, the intensity of this process will be also controlled by the genotype, since for the same climate conditions some cultivars present flowers whereas others not (Shanmugavadivu and Rao, 2009).

Another aspect related to the flowering refers to the pith process, which is characterized by the drying of the stalk's top (Silva and Caputo, 2012). The pith process

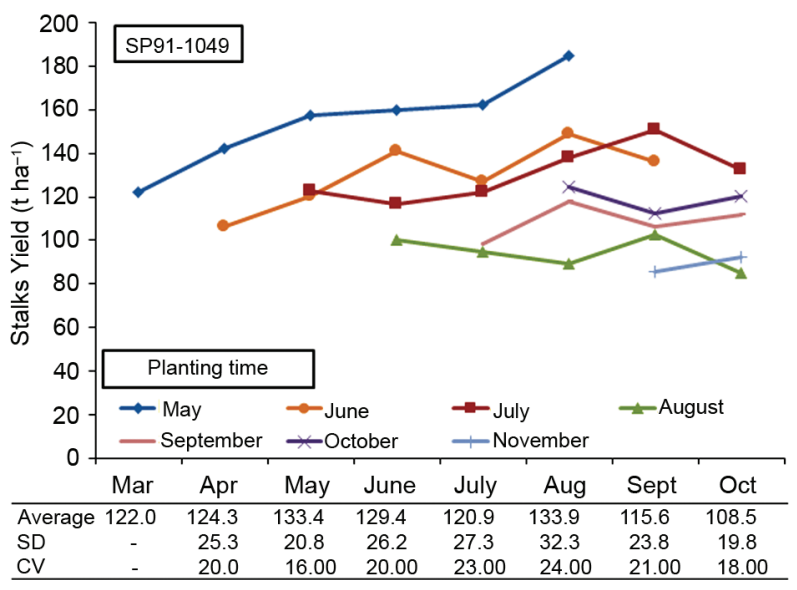

Figure 2 - Stalk yields of sugarcane cultivar SP91-1049 during the months of the 2003 season as function of planting time in Piracicaba, State of São Paulo, Brazil. Source: Cardozo (2012). 
leads to juice reduction and fiber increase, making the sucrose extraction more difficult in the industry.

Resuming, sugarcane flowering is a climate dependent process that affects not the ripening by itself but the sucrose content since it consumes the reserves for the panicle formation and emission.

\section{Effects of meteorological conditions on sugarcane ripening}

Meteorological variables are the primary variables responsible for the productivity and quality of sugarcane (Keating et al., 1999). Low temperatures and moderate water deficits associated with nitrogen deficiency are the most effective ripening agents (Alexander, 1973). As growth rates decrease, a lower amount of sugar is used in new tissue formation, and a greater amount of sucrose is stored. During ripening, sucrose levels in stalks gradually increase as the percentage of glucose and fructose decreases (Clements, 1962). Therefore, in most of the humid tropical and subtropical regions, as the sugarcane crop approaches to the harvest, the dry season and the low temperatures slow down the sugarcane growth, forcing the conversion of reducing sugars into sucrose (Clements, 1962). However, the influence of weather conditions on the ripening process is still debated, and some authors have proposed that, in addition to air temperature and soil moisture, variables such as the photoperiod and solar radiation must also be considered (Legendre, 1975). Climatic variables have significant correlations with sugarcane ripening (Table 2) and must be analyzed considering long periods of time preceding the harvest (120 to 150 days) because their actions on the plants' metabolism and physiology are not immediate (Cardozo, 2012).

The environmental conditions influence the invertases in sugarcane, which are active enzymes in the ripening and growth processes (Alexander, 1973; Lingle and Irvine, 1994). Under conditions of high air temperature and soil moisture, changes in invertase balance result in intense growth; additionally, sucrose accumulation decrease, delaying ripening. Glasziou and Bull (1965) and Alexander (1973) reported that high levels of acid invertase (optimum $\mathrm{pH}$ 5.1) and low levels of neutral invertase (optimum $\mathrm{pH}$ 7) are associated with

Table 2 - Pearson coefficient of correlation between Pol of eight sugarcane cultivars and meteorological variables accumulated during different periods of time (30 to 150 days) before sampling in Piracicaba, State of São Paulo, Brazil.

\begin{tabular}{lccccc}
\hline \multirow{2}{*}{ Meteorological Variable } & \multicolumn{5}{c}{ Days before harvest } \\
\cline { 2 - 6 } & 30 & 60 & 90 & 120 & 150 \\
\hline Minimum air temperature & -0.49 & -0.80 & -0.87 & -0.91 & -0.92 \\
Sunshine hours & -0.10 & 0.47 & 0.43 & 0.79 & 0.89 \\
Precipitation & -0.69 & -0.84 & -0.88 & -0.92 & -0.93 \\
Photoperiod & 0.10 & -0.30 & -0.64 & -0.82 & -0.90 \\
Global solar radiation & 0.44 & 0.22 & -0.33 & -0.67 & -0.78 \\
\hline
\end{tabular}

Adapted from Cardozo (2012). vigorous vegetative growth, while the opposite conditions are associated with ripening. Acid invertase has high activity under favorable growth conditions and low activity under unfavorable conditions, such as when water or nutritional stresses, short photoperiod and low air temperature occur (Tymowska-Lalanne and Kreis, 1998). Lingle (1997) also observed that reductions in acid invertase activity were accompanied by increases in the total concentrations of sugar and sucrose, leading to the conclusion that this enzyme suppresses sugar accumulation. Acid invertase activity decreases in cold conditions, likely due to the increased activity of sucrose phosphate synthetase and neutral invertase, with a consequent increase in sucrose concentration (Terauchi et al., 2000).

\section{Solar radiation and photoperiod}

By analyzing differences in the growth and ripening of sugarcane cultivars in two locations in Hawaii, Clements (1940) concluded that differences in sugar yield were more influenced by solar radiation than by air temperature, and cloudy days represented a limiting factor for ripening. Clements (1940) noted that sucrose levels were higher in areas where solar radiation was more intense (due to the absence of clouds), although the soil moisture in these two areas were the same in the three months before harvest. Legendre (1975) also reported that the solar radiation was more directly related to sugarcane ripening than factors such as air temperature and precipitation. However, the influence of solar radiation has been strongly correlated with cultivar characteristics, which led the author to emphasize the importance of the interaction between genotypes and meteorological variables.

Alexander (1973), Glasziou et al. (1964) and Shaw (1953) have showed the importance of the photoperiod in sugarcane ripening. Shaw (1953) reported that maximum values of sucrose accumulation were found in the latitudes between of $18{ }^{\circ} \mathrm{N}$ and $18^{\circ} \mathrm{S}$ and suggested that this effect was due more to the day length (photoperiod) over the critical period of ripening than to the air temperature. However, Glasziou et al. (1965) suggested that the effects observed by Shaw (1953) were due to an optimal combination between seasonal variations of air temperature and the photoperiod in these locations. At latitudes close to the Equator, variations in air temperature may be too small to lead to sugarcane to ripening, while in middle latitudes, the day length during the winter can be very short, reducing the time available for photosynthesis to the detriment of the sugar accumulation process. Cardozo (2012) studied the relationships between solar radiation $(\mathrm{SR})$, net radiation $(\mathrm{NR})$, photoperiod $(\mathrm{N})$ and ripening patterns of some sugarcane cultivars and observed inversely proportional relationships between SR, $\mathrm{NR}$ and $\mathrm{N}$ and sugarcane quality variables such as the total solids content present in the juice (Brix), Pol and total recoverable sugar (TRS) when these variables were averaged for 90 to 150 days before sampling. 


\section{Air temperature}

Air temperature is directly related to sugarcane growth and ripening processes. Burr et al. (1957) observed a reduction of $84 \%$ in the rate of sugarcane photosynthesis when air temperature was reduced from 23.0 to $13.6{ }^{\circ} \mathrm{C}$. Waldron et al. (1967) showed that the photosynthetic efficiency decreased linearly with a decrease in air temperature in the range from 34 to $5{ }^{\circ} \mathrm{C}$. The effects of air temperature on the photosynthesis rate and on the efficiency of this process are directly related to crop vegetative development (Alexander, 1973). Accordingly, Stender (1924) demonstrated a close relationship between stalk length and diameter and air temperature, with a reduction in stalk growth rates during the winter to one-third of those observed in the summer. The reduction in stalk growth rates, either in length or diameter, is followed by an increase in the rate of sucrose accumulation (Mamet and Galwey, 1999).

Alexander (1973) described the process of sugarcane physiological ripening as dependent on the seasonal reduction of air temperature, which slows growth rates. However, this reduction in growth rates occurs without significantly affecting the photosynthetic process, so that there are more photosynthates converted into sucrose to be stored in plant tissues. Two of the most important variables associated with sugarcane ripening are the leaf sheath moisture index and the average air temperature in the three months prior to harvest (Clements, 1962). Both variables show a strong inverse relationship with Brix, i.e., the lower the moisture index and the cooler the evenings, more favorable the conditions for ripening. Yates (1972) found that the low air temperatures promoted ripening more effectively than low soil moisture. These results were also reported by Glover (1971), who suggested that in places where there is no water deficiency, the average air temperature needs to be lower than 21 ${ }^{\circ} \mathrm{C}$ for three months to begin the ripening process.

Cardozo (2012) noted an inversely proportional relationship between air temperature and sugarcane ripening, with higher correlation coefficients observed when the air temperature was averaged in the last 120 to 150 days before sampling, which agrees with Clement (1962) findings. Glasziou et al. (1964) showed that high sugar content was produced when the air temperature was reduced over a long period of time. According to Glasziou et al. (1964), the sugar concentration did not exceed $12 \%$ of the fresh weight when the air temperature was constant or when small daily temperature variations occurred. However, when the average air temperature was reduced for a long period of time, i.e., three to six months, sugar concentration reached $17 \%$ of the fresh weight. Reductions in air temperature promote a decrease in the acid invertase concentration in stalks, an increase in the concentration of neutral invertase, and a consequent increase in the sucrose content of the stalks (Alexander and Samuels, 1968; Ebrahim et al., 1998). However, the reduction in acid invertase levels only occurs with a prolonged reduction of air temperature (Lin- gle, 2004), which confirms the information obtained by Glasziou et al. (1964).

Glasziou et al. (1964) observed the occurrence of sugar losses when sugarcane plants that had reached high sucrose levels were transferred from environments with low to high air temperatures. The effects of the high air temperature on the reduction of sucrose content were observed after 35 consecutive days, which means that the process of reducing the sucrose levels was significantly faster than that of its accumulation (3-6 months). These results dismissed the belief that daily variations in air temperature could induce sugarcane ripening, which allowed the inference that the sugarcane plants are much more responsive to climatic variables that favor vegetative growth than those that favor ripening.

There is no consistency regarding the thermal parameters of sugarcane, primarily related to base temperatures, since there are numerous base temperature values proposed, which may vary according to the location, cultivars and phenological phase (Scarpari and Beauclair, 2004, 2009). Barnes (1964) found that the base temperature for shoot emergence is $12{ }^{\circ} \mathrm{C}$, while Inman-Bamber $(1991,1994)$ found a base temperature of $16{ }^{\circ} \mathrm{C}$ for tillering. Bacchi and Souza (1977) reported values between 18 and $19{ }^{\circ} \mathrm{C}$ for the internode elongation process. These values were also reported by Liu et al. (1999) when evaluating two sugarcane cultivars. O'Callaghan et al. (1994) suggested a constant base temperature for all sugarcane processes and phenological phases, equal to $8{ }^{\circ} \mathrm{C}$.

For ripening process, Scarpari and Beauclair, (2004, 2009) found that temperatures below $20{ }^{\circ} \mathrm{C}$ slow down sugarcane growth rates and increase sucrose accumulation in stalks. As sugarcane ripening is related to a reduction in air temperature, Scarpari and Beauclair (2004) proposed a method for correlating such variables, called the sum of negative degrees days, which is similar to the concept of chilling hours. For the negative degree day accumulation for sugarcane, temperatures between 0 and 7 ${ }^{\circ} \mathrm{C}$ should not be considered because below $7{ }^{\circ} \mathrm{C}$ carbon assimilation is negatively affected, as is the stomatal conductance and the photosynthetic rate, which determine the magnitude of the gas exchange of the following day (Scarpari and Beauclair, 2004, 2009). As a result of the reduction on carbon assimilation, there is a decrease on the sucrose translocation to stalks (Waldron et al., 1967; Grantz, 1989), and there is an accumulation of sucrose in the leaf cells in an attempt to decrease the matric potential and the freezing temperature of the tissues.

Cardozo (2012) evaluated eight sugarcane cultivars and found variation of their base temperature, with the earliest cultivars (SP91-1049 and SP86-155) exhibiting higher values, between 20 and $21^{\circ} \mathrm{C}$, while the middle (RB867515) and late ripening cultivars (SP83-2847) exhibited smaller values, between 18 and $19{ }^{\circ} \mathrm{C}$. According to Cardozo (2012), this fact explained the precocity of some cultivars in relation to others because the higher the base temperature, the smaller the growth under low 
air temperatures. Late cultivars are less sensitive to low air temperature than the early ones; thus, they continue their growth for longer periods, delaying their ripening.

\section{Soil moisture}

In addition to the air temperature, soil moisture can also affect sugarcane ripening. In tropical areas, where air temperature is not a limiting factor, ripening is induced primarily by the exhaustion of nitrogen supplies and by soil water availability (Humbert, 1968; Tianco and Escober, 1970; Alexander, 1973). Water stress, caused by low soil water availability, influences the photosynthetic rate, causing severe reduction in carbohydrate synthesis, leaf expansion and internode elongation. This is followed by an increase in the sucrose content due to reduced demand for sugars in the meristematic tissues (Alexander, 1973).

Although water deficits lead to the changes already discussed in this review, the impact on the final yield is small, due to the short time of exposure and to the fact that at the ripening stage, plants usually have stalks already formed (Wiedenfeld, 2000). Biomass accumulation in stalks is affected when the water deficit is greater than $120 \mathrm{~mm}$, while sucrose accumulation is affected only with water deficits greater than $145 \mathrm{~mm}$ (Inman-Bamber, 2004). Scarpari and Beauclair (2004) also reported that an accumulated water deficit greater than $130 \mathrm{~mm}$ in the months before harvest is positive for sucrose accumulation in stalks.

The ideal water deficit for this process is not well defined because this value also depends on other variables, such as the evapotranspiration rate, the soil water holding capacity (SWHC) and the crop phenological phase (Scarpari and Beauclair, 2004, 2009). Few researchers have discussed the influence of water deficit on sugarcane crops, and those have focused on the later crop phenology stages, primarily on the influence of the management of drying-off on biomass and sugar accumulation (Thompson, 1977; Robertson and Donaldson, 1998). Therefore, there is a need for a better understanding of the consequences of changes in the time of drying-off and the duration of water deficit on biomass and sugar yields.

Several authors have described the effects of water deficits on processes such as leaf expansion and stalk elongation (Hill, 1966; Kingston and Ham, 1975; Jones, 1980; Koehler et al., 1982; Inman-Bamber and De Jager, 1988; Roberts et al., 1990; Nable et al., 1999), leaf senescence (Inman-Bamber and De Jager, 1988; Inman-Bamber, 1994), sucrose content, dry matter (Inman-Bamber and De Jager, 1988) and photosynthesis (Roberts et al., 1990). However, recent studies have shown that tillering and intense growth phases are the most critical to water deficit, since the most of sugarcane biomass is produced during these periods (Ramesh and Mahadevaswamy, 2000; Inman-Bamber and Smith, 2005).

There is compensatory growth in sugarcane crops when they are irrigated after having been exposed to wa- ter deficit at the beginning of their development (Robertson et al., 1999). The effects of water deficit on growth can be compensated by an increase in the tillering rate and the emergence of new leaves because the plants are exposed to satisfactory soil water availability (Robertson et al., 1999). Inman-Bamber (1994) reported that sugarcane plants subjected to irrigation after the occurrence of a period with water deficit increased their rate of stalk elongation up to 1.6-fold when compared to plants without water restriction. However, a water deficit in the internodes elongation phase had a serious impact on total biomass and sugar yield.

The effects observed when water deficits occur during tillering and the stalk elongation phases contrast with the results found in treatments with later deficits, near the harvest. When the water deficit occurs close to the harvest, the sucrose concentration can increase up to $15 \%$, with average values of approximately $8 \%$ (Robertson and Donaldson, 1998). According to these authors, the increase in the sucrose concentration occurred due to an increase in soluble solids and dehydration. However, this increase in sucrose production occurred when the stalk dry matter weight reduction was less than 10 $\%$. This relationship can be used as the basis for the determination of the threshold between the reduction in stalk biomass and sucrose production under several schemes of irrigation suspension (drying-off) (Robertson and Donaldson, 1998).

Cardozo (2012) studied the effects of a water deficit on sugarcane ripening and found that there is a high correlation between the conditions of regional water availability (accumulated water surplus or deficit) and the quality of sugarcane juice. The water deficit is directly related to the ratio of variables Brix, Pol, TRS and purity, with Pearson linear correlation values greater than 0.95 . Cardozo (2012) also evaluated the effects of precipitation on sugarcane quality and found that rainfall accumulated during 120 days before harvest had high correlation values $(\mathrm{r}=-0.95)$ with sugarcane ripening.

\section{Chemical ripening}

When natural conditions are not enough for promoting sugarcane ripening, the growers can opt by the use of chemical products for forcing the plants to ripen. These chemicals are plant growth regulators or inhibitors known as ripeners and affect the plants by different ways. They can modify the morphology and physiology of the plants, which can lead to quantitative and qualitative changes in production by promoting reduction in plant growth and increase in sucrose content, anticipating the ripening and enhancing the sugar yield (Silva and Caputo, 2012).

The use of ripeners in the sugarcane production system has provided greater flexibility in managing the harvest. The feasibility of their use depends on cultivar and climatic, technical and economic conditions (Langedre, 1975; Dalley and Richard Junior, 2010; Silva and Caputo, 2012). Regarding the climatic conditions, the 
use of ripeners for stimulating sucrose accumulation in sugarcane is mainly recommended when high temperatures and/or rainy periods are observed, which is more common in the beginning and in the ending of the harvest season in Southeastern Brazil.

\section{Final Remarks}

Sugarcane ripening involves a complex combination of climate variables, the genetic potential of cultivars and agricultural management. Ripening is not synonymous with aging or stalk maturity but is a natural process of sucrose accumulation as a reserve for adverse environmental conditions. Among the climatic variables related to ripening, water deficits and air temperature are the most commonly cited. Under the conditions of the most important Brazilian producing areas, water restriction is the primary variable related to ripening. Water restriction has a direct effect on increasing sucrose in the stalks by an active accumulation mechanism and an indirect effect by stalk dehydration, making the ripening process more intense than under the influence of low temperatures. The seasonal reduction in air temperature also affects the ripening process, but its action is less intense and requires more time to impact sugar accumulation. We conclude that there is a need for studies that demonstrate the effects of climatic variables on plant physiology, especially in the balance of enzymes that regulate the processes of sugarcane vegetative growth and ripening, and studies that determine the causes of variation in the behavior of commercial varieties. We also suggest that a better understanding of the effect of climatic conditions on ripeners actions should be investigated in order to provide reliable information for growers about how and when to use these products with higher efficiency.

\section{References}

Alexander, A.G. 1973. Sugarcane Physiology. Elsevier, Amsterdam, Netherlands.

Alexander, A.G.; Samuels, G. 1968. Controlled-temperature studies of growth, enzymology, and sucrose production by two sugarcane varieties in Puerto Rico. Journal of Agriculture 52: 204-217.

Bacchi, O.O.S.; Souza, J.A.G.C. 1978. Minimum threshold temperature for sugar cane growth. Proceedings of the Congress of the International Society of Sugar Cane Technologists 2. p. 1733-1741. ISSCT, São Paulo, SP, Brazil.

Barnes, A.C. The Sugar Cane. 1964. Interscience, New York, NY, USA.

Brodie, H.W.; Yoshida, R.; Nickell, L.G. 1969. Effect of air and root temperatures on growth of four sugarcane clones. Hawaiian Planters Record 58: 21-52.

Burr, G.O.; Hartt, C.E.; Brodie, H.W.; Tanimoto, T.; Kortschak, H.P.; Takahashi, D.; Ashton, F.M.; Coleman, R.E. 1957. The sugarcane plant. Annual Review of Plant Physiology 8: 27530.
Cardozo, N.P. 2012. Modeling sugarcane ripening as function of meteorological variables. Available at: < http://www.teses.usp. br/teses/disponiveis/11/11131/tde-14032012-080359/> [Acessed July 07, 2012]

Clements, H.F. 1940. Integration of climatic and physiologic factors with reference to the production of sugar cane. Hawaii Planters Research 44: 201-233.

Clements, H.F. 1962. The ripening of sugar cane. Sugar y Azúcar 57: 29-78.

Clements, H.F. 1968. Lengthening versus shortening dark periods and blossoming in sugarcane as affected by temperature. Plant Physiology 4: 57-60.

Dalley, C.D.; Richard Junior, E.P. 2010. Herbicides as ripeners for sugarcane. Weed Science 58: 329-333.

Ebrahim, M.K.; Zingsheim, O.; El-Shourbagy, M.N.; Moore, P.H.; Komor, E. 1998. Growth and sugar storage in sugarcane grown at temperatures below and above optimum. Journal of Plant Physiology 153: 593-602.

Evensen, C.I.; Muchow, R.C.; El-Swaify, S.A.; Osgood, R.V. 1997. Yield accumulation in irrigated sugar-cane. I. Effect of crop age and cultivar. Agronomy Journal 89: 638-646.

Glasziou, K.T.; Bull, T.A. 1965. The relation between total invertase activity and internode expansion in sugar-cane stalks. Proceedings of the International Society Sugarcane Technologists Congress 12. p. 575-681. Elsevier, Amsterdam, Netherlands.

Glasziou, K.T.; Bull, T.A.; Hatch, M.D.; Whiteman, P.C. 1964. Physiology of sugarcane. VII. Effects of temperature, photoperiod duration, and diurnal and seasonal temperature changes on growth and ripening. Australian Journal of Biological Sciences 18: 53-66.

Glover, J. 1971. Changes in sucrose \% cane and yield of sucrose per unit area associated with cold, drought and ripening. Proceedings of the South African Sugarcane Technologists' Association 46. p. 158-164. SASTA, Durban, South Africa.

Grantz, D.A. 1989. Effect of cool temperatures on photosynthesis and stomatal conductance in field-grown sugarcane in Hawaii. Field Crops Research 22: 143-155.

Hill, J.N.S. 1966. Availability of soil water to sugarcane in Natal. Proceedings of the Annual Congress South African Sugar Technologists' Association 41: 276-282. SASTA, Pretoria, South Africa.

Humbert, R.P. 1968. The Growing of Sugar Cane. Elsevier, Amsterdam, Netherlands.

Inman-Bamber, N.G. 1991. Growth model for sugarcane based on a simple carbon balance and the CERES-Maize water balance. South African Journal of Plant Soil 8: 93-99.

Inman-Bamber, N.G. 1994. Temperature and seasonal effects on canopy development and light interception of sugarcane. Field Crop Research 36: 41-51.

Inman-Bamber, N.G. 2004. Sugarcane water stress criteria for irrigation and drying off. Field Crops Research 89: 107-122.

Inman-Bamber, N.G.; De Jager, J.M. 1988. Effect of water stress on sugarcane stalk growth and quality. Proceedings of the Annual Congress South African Sugar Technologists' Association 62. p. 140-144. SASTA, Pretoria, South Africa.

Inman-Bamber, N.G.; Smith, D.M. 2005. Water relations in sugarcane and response to water deficits. Field Crops Research 92: 185-202. 
Inman-Bamber, N.G.; Bonnett, G.D.; Spillman, M.F.; Hewitt, M.L.; Xu, J. 2009. Source-sink differences in genotypes and water regimes influencing sucrose accumulation in sugarcane stalks. Crop and Pasture Science 60: 316-327.

Jones, C.A. 1980. A review of evaporation studies in irrigation sugarcane in Hawaii. The Hawaiian Planters' Record 50: 195214.

Keating, B.A.; Robertson, M.J.; Muchow, R.C.; Huth, N.I. 1999. Modelling sugarcane production systems. I. Development and performance of the sugarcane module. Field Crops Research 48: 27-36.

Kingston, G.; Ham, G.J. 1975. Water requirements and irrigation scheduling of sugarcane in Queensland. I. Water requirements of sugarcane in Queensland. In: Proceedings of the Conference of Queensland Society of Sugarcane Technologists 42. p. 57-65. QSST, Townsville, Australia.

Koehler, P.H.; Moore, P.H.; Jones, C.A.; Cruz, A.D.; Maretzki, A. 1982. Response of drip-irrigated sugarcane to drought stress. Agronomy Journal 74: 906-911.

Lavanholi, M.G.D.P. 2008. Sugarcane qualitiy as raw material for sugar and ethanol production. = Qualidade da cana-deaçúcar como matéria-prima para produção de açúcar e álcool. p. 697-722. In: Dinardo-Miranda, L.L.; Vasconcelos, A.C.M.; Landell, M.G.A., ed. Sugarcane = Cana-de-açúcar. Instituto Agronômico, Campinas, SP, Brazil (in Portuguese).

Legendre, B.L. 1975. Ripening of sugarcane: effects of sunlight, temperature, and rainfall. Crop Science 15: 349-352.

Leite, G.H.P.; Cruciol, C.A.C.; Silva, M.A.; Lima, G.P.P. 2011. Invertases enzymes activity and sucrose accumulation in sugarcane (Saccharum officinarum L.) under effect the potassium nitrate, ethephon and ethyl-trinexapac. Ciência Agropecuária 35: 649-656 (in Portuguese, with abstract in English).

Lingle, S.E. 1997. Seasonal internode development and sugar metabolism in sugarcane. Crop Science 37: 1222-1227.

Lingle, S.E. 2004. Effect of transient temperature change on sucrose metabolism in sugarcane internodes. Journal American Society of Sugarcane Technologists 24: 132-141.

Lingle, S.E.; Irvine, J.E. 1994. Sucrose synthase and natural ripening in sugarcane. Crop Science 34: 1279-1283.

Liu, D.L.; Kingston, G.; Bull, T.A. 1999. A new technique for determining the thermal parameters of phenological development in sugarcane, including sub optimum and supra-optimum temperature regimes. Agricultural and Forest Meteorology 90: 119-139.

Mamet, L.D.; Galwey, N.W. 1999. A relationship between stalk elongation and earliness of ripening in sugarcane. Experimental Agriculture 35: 283-291.

Nable, R.O.; Robertson, M.J.; Berthelsen, S. 1999. Response of shoot growth and transpiration to soil drying in sugarcane. Plant and Soil 207: 59-65.

O'Callaghan, J.R.; Hossain, A.H.M.S.; Dahah, M.H.; Wyseure, G.C.L. 1994. SODOCOM: A solar driven computacional model of crop growth. Computers and Electronics in Agriculture 11: 293-308.

Pereira, A.R.; Barbieri, V.; Villa Nova, N.A. 1983. Climatic conditioning of flowering induction in sugarcane. Agricultural Meteorology 29: 103-110.
Ramesh, P.; Mahadevaswamy, M. 2000. Effect of formative phase drought on different classes of shoots, shoot mortality, cane attributes, yield and quality of four sugarcane cultivars. Journal of Agronomy and Crop Sciences 185: 249-258.

Roberts, J.; Nayamuth, R.A.; Batchelor, C.H.; Soopramanien, G.C. 1990. Plant-water relations of sugarcane (Saccharum officinarum L.) under a range of irrigated treatments. Agricultural Water Management 17: 95-115.

Robertson, M.J.; Donaldson, R.A. 1998. Changes in the components of cane and sucrose yield in response to drying-off of sugarcane before harvest. Field Crops Research 55: 201-208.

Robertson, M.J.; Muchow, R.C.; Donaldson, R.A.; Inman-Bamber, N.G.; Wood, A.W. 1999. Estimating the risk associated with drying-off strategies for irrigated sugarcane before harvest. Australian Journal of Agricultural Research 50: 65-77.

Scarpari, M.S.; Beauclair, E.G.F. 2004. Sugarcane maturity estimation through edaphic-climatic parameters. Scientia Agricola 61: 486-491.

Scarpari, M.S.; Beauclair, E.G.F. 2009. Physiological model to estimate the maturity of sugarcane. Scientia Agricola 66: 622628.

Shanmugavadivu, R.; Rao, P.N.G. 2009. A comparison of flowering behavior of sugarcane clones in two different locations. Sugar Tech 11: 401-404.

Shaw, H.R. 1953. An international glance at sucrose content of cane. Proceedings of the Congress of the International Society of Sugarcane Technology 8. p. 283-289. Kingston, Canada.

Silva, M.A.; Caputo, M.M. 2012. Ripening and the use of ripeners for better sugarcane management. p. 2-24. In: Marin, F.R., ed. Crop management: cases and tools for higher yield and sustainability. InTech, Rijeka, Croatia.

Singh, S.; Venkatarama, S. 1983. Physiological studies on growth and sucrose accumulation in early and late maturing varieties of sugarcane. p. 104-107. In: Coimbatore Sugar Breeding Institute. Annual report. CSBI, Coimbatore, India.

Stender, H.K. 1924. Some sugar cane growth measurements. Hawaiian Planters' Record 28: 472-495.

Terauchi, T.; Matsuoka, M.; Kobayashi, M.; Nakano, H. 2000. Activity of sucrose phosphate synthase in relation to sucrose concentration in sugarcane internodes. Japan Journal Tropical Agriculture 44: 141-151.

Thompson, G.D. 1977. Irrigation of sugarcane. South African Sugar Journal 61: 126-131.

Tianco, A.P.; Escober, T.R. 1970. Chemical ripening of sugarcane with CP 41845. Sugar News 46: 508-531.

Tymowska-Lalanne, Z.; Kreis, M. 1998. The plant invertases: physiology, biochemistry and molecular biology. Advances in Botanical Research 28: 71-117.

Waldron, J.C.; Glasziou, K.T.; Bull, T.A. 1967. The physiology of sugar cane. IX. Factors affecting photosynthesis and sugar storage. Australian Journal of Biological Sciences 20: 1043-1052.

Wiedenfeld, R.P. 2000. Water stress during different sugar cane growth periods on yield and response to $\mathrm{N}$ fertilizer. Agricultural Water Management 43: 173-182.

Yates, R.A. 1972. Effects of environmental conditions and the coadministration of growth retardants on the response of sugarcane to foliar treatment with gibberellin. Agronomy Journal 64: 31-35. 